\title{
Recommendations regarding Religious Groups and Institutions
}

The following section reproduces policy recommendations for religious groups and institutions how to fight antisemitism as they were developed for the Catalogue of Policies to Combat Antisemitism. ${ }^{1}$ These policies grew out of all research presented at the conference "An End to Antisemitism!" in Vienna, February 18-22, 2018. This research pertains to antisemitic traditions in Christianity and Islam and to the contribution these religions could make to the fight against antisemitism. It also engages with effects of antisemitism on Judaism and its representations within Judaism.

The contributions in questions can be found in the previous section of this volume. Further articles that contributed to the recommendations presented below are published in volumes 2 and 3 of the conference proceedings An End to Antisemitism!, both forthcoming.

Even more so than in other areas, in the world of religion, policies combating antisemitism should aim for a timeframe of several generations. It is near to impossible to erase the deeply rooted antisemitic stereotypes in Christian and Muslim traditions from the religious memories of these two religions. While such a total absence of antisemitism in these two religious traditions might sound like a utopian goal, it is nevertheless important to aspire to it as the most desirable condition toward which all policies combating antisemitism should aim. It is hoped that this goal might actually be achieved in a timespan of several generations.

The level of antisemitism is different in each religious group and/or institution. Radical Islamist terrorist organizations such as ISIS or Al Qaida as well as Christian white supremacist groups such as the KKK with its American and European chapters or the Aryan Nations/Church of Jesus Christ-Christian and other parts of the Christian Identity Movement are examples of the most extreme antisemitic religious groups and organizations.

In other religious groups or organizations, a significant part of the clergy and the members are actively philosemitic, while others still adhere to Jew-hatred. An example of the latter case would be the Catholic Church: Pope Francis and many members of the Catholic clergy are friends of Judaism while the Polish Catholic radio station Radio Maryja is described by the US State Department's Global

1 A. Lange, A. Muzicant, D. Porat, L. H. Schiffman, M. Weitzman, An End to Antisemitism! A Catalogue of Policies to Combat Antisemitism (Brussels: European Jewish Congress, 2018), 31-49.

Ә OpenAccess. (c 2019, Armin Lange, Kerstin Mayerhofer, Dina Porat, Lawrence H. Schiffman, published by De Gruyter. (cc) BY-NC-ND This work is licensed under the Creative Commons Attribution-NonCommercialNoDerivatives 4.0 License https://doi.org/10.1515/9783110618594-021 
Anti-Semitism Report of 2008 as “one of Europe's most blatantly anti-Semitic media venues."2 Between radical antisemitic religious groups and philosemitic religious groups, a large grey zone of different levels of antisemitism inside religious groups and organizations exists.

The combating of antisemitism in religious groups or organizations has to follow different strategies depending on the level of antisemitism in them. In the case of radically antisemitic religious groups, strategies to combat their antisemitism can only be applied from the outside. In the case of those religious groups in which the level of antisemitism is not too high, strategies for combating antisemitism can be developed and applied from the inside.

Policies for combating antisemitism in religious groups need to address different elements:

- A commitment to eradicating antisemitic opinions within the clergy of religious groups or organizations

- Fighting and removing antisemitic stereotypes and canards from the religious memory of a religious group or institution

- Emphasizing the positive aspects of Judaism in a religious memory and adding new positive contents about Judaism to a religious memory

- Removing the authority of antisemitic role models such as saints or highly respected authorities that provide guidance to the members of a religious group or institutions Examples include John Chrysostom, Martin Luther and others

- Removing antisemitism from the religious laws and doctrines of a religious group or organization

- Removing antisemitism from the private beliefs of the members of a religious group or organization.

Many of the measures that need to be taken to eradicate the antisemitism of religious groups and organizations will only be effective on a long-term basis as they require changes in their religious memory. While on a mid-term and short-term basis, changes in the institutional framework and the religious law of religious groups and organizations might be achieved, the key to the eradication of antisemitism in a religious group or organization is to change both the minds of its members as well as its cultural and religious heritage. The latter two require a continuous effort over generations.

2 United States Department of State, Contemporary Global Anti-Semitism: A Report Provided to the United States Congress (released March 2008), 5, https://2009-2017.state.gov/documents/ organization/102301.pdf. 
To achieve these aims we advise five additional steps.

1. Assessment: Assessing where a religious institution or a religious group stands regarding its level of antisemitism.

2. Comprehending the problem: Analyzing which religious traditions create Jew-hatred inside a religion, a religious group, or a religious institution.

3. Awareness-raising: Clergy and lay people need to be alerted to the antisemitism inherent in their religion.

4. Application of policies for combating antisemitism.

5. Adjusting the general policies to combat antisemitism: The general policies suggested below for Christian, Muslim, and Jewish groups and organizations need to be adjusted to the specific needs of each religious institution, religious group, and religious organization.

\section{Religious Groups or Institutions and Combating Antisemitism}

Religious groups and institutions have a special capability in combating antisemitism given the religious character of the antisemitic ideology of most, if not all, antisemitic groups. We argue that, the very irrationality of antisemitism identifies it as a religious phenomenon, that is, as a belief system. In addition to fighting antisemitism inside their own organizational framework, religious groups and institutions thus have a responsibility to address antisemitism outside their own religious group or organization. This is all the more the case as the Christian and Muslim heritage is responsible for much of today's antisemitism. Those religious groups and organizations whose level of antisemitism is low should therefore be actively involved in encouraging antisemites to change their religious orientation from a religion of hate to a religion of love and mutual respect that includes the love of and respect for Judaism.

Religious denominations that practice acts of terror and hate crimes, such as the churches and organizations of the Christian identity movement of ISIA, need to be prosecuted by legal and law enforcement institutions. Their leaders and those members that committed crimes are subject to the judiciary, the executive, and law enforcement agencies. Members of such religious terrorist groups that did not become criminals should be religiously educated and missionized by denominations of their religion whose level of antisemitism is low. The reader is referred for the combating of religious terrorist groups to the recommendations 
of the OSCE's “Understanding Anti-Semitic Hate Crimes and Addressing the Security Needs of Jewish Communities: A Practical Guide."3

Below we will first outline policy recommendations that apply to all religious groups, organizations and institutions. In a second step we will then make some recommendations specific to Judaism, Christianity, and Islam.

\subsection{Assessing the Level of Antisemitism within a Religious Group, Organization, or Institution}

In cooperation with Jewish organizations, institutions need to be created that are able to assess the level of antisemitism inside each religious group, organization or institution by way of regular surveys. Ideally, such assessment institutions should be independent scholarly/scientific organizations whose independence vouches for an uncompromised assessment and whose expertise warrants the highest quality of antisemitism assessment. Assessments of the level of antisemitism inside a religious group, organization, or institution should be repeated on a regular basis to allow for an appreciation of how effective efforts at the combating of antisemitism were.

\subsection{Comprehending the Problem: Analyzing which Religious Traditions Create Jew-hatred inside a Religion, a Religious Group, or a Religious Institution}

Holy Writ such as the New Testament or the Qur'an, as well as the writings of authoritative religious authors, doctrinal texts and religious laws need to be scrutinized for antisemitic contents. In Christianity, such texts would include the writings of saints like Ambrose of Milan or reformers like Martin Luther, the dogmatic tradition, church law and teaching. In Islam, we are concerned with different parts of Hadith and Sira. Only when the antisemitic contents in the religious memories of Christianity and Islam are properly identified, will it be possible to combat antisemitism inside the various denominations, groups, and organizations of these two religions.

3 Organization for Security and Co-operation in Europe, Understanding Anti-Semitic Hate Crimes and Addressing the Security Needs of Jewish Communities: A Practical Guide, May 15, 2017, https://www.osce.org/odihr/317191?download=true. 
Particularly problematic communicators of antisemitism in religious memories are school- and textbooks as well as liturgies. Schoolbooks, textbooks and liturgical texts should therefore be scrutinized regularly for antisemitic contents (see recommendations regarding education). It needs to be emphasized that these regular surveys need to pertain not only to stereotypes and canards that are openly antisemitic but also to tropes of religious thought such as Christian replacement theology (see below, 222).

These surveys for antisemitic content in the religious memory of Christian churches, groups and institutions should be done regularly by neutral scholarly institutions in cooperation with Jewish scholars and organizations. The results of these surveys should be published in a form that is easily accessible for lay people and clergy alike.

\subsection{Awareness-raising: Clergy and Lay People Need to Be Alerted to the Antisemitism Inherent in their Religion}

In Holy Scriptures, divine messages are always communicated through human beings. God's revelation is thus marred by human fallibility. Beginning with the New Testament, divine revelation expresses itself in Christian holy texts that also express a form of hatred. The manifestations of this hatred resulted in a tradition of antisemitism that gave moral legitimacy to crimes against the Jewish people, the epitome of which is the Shoah. Once the antisemitic contents of a religious memory are identified, not only the decision makers, clergy and other elites of religious groups, organizations or institutions need to be alerted to them but also all of their members. Only if all members of a religious group, organization or institution develop an awareness of the antisemitic content of their traditions, are changes possible.

To raise the awareness of Christians and Muslims towards the antisemitic contents of their religious memories is not a one-time effort but an ongoing process. Awareness of antisemitic contents in religious memories needs to be achieved for each generation anew to immunize it against Jew-hatred.

Examples how such a continuous awareness raising can be achieved are the following:

- Translations of the New Testament, the Qur'an and other Christian or Muslim literatures need marginal glosses and introductions that emphasize continuity with Jewish heritage of both Christianity and Islam and warn readers about antisemitic passages in them. While some efforts have been made in this direction in the case of Christianity, these efforts need to be extended and made consistent in both religions. 
- Canonical or quasi-canonical writings of religious antisemites (such as Luther's On the Jews and their Lies or Sayyid Qutb's Our Struggle against the Jews. a seminal work of modern Islamic fundamentalism) need to be publicly denounced as unholy writ by mainstream religious leaders and thinkers.

- All antisemitic texts and passages in the heritage of Christianity and Islam need to be identified and rejected. The identification should best be achieved by the institutes for antisemitism studies recommended in the present chapter on academic organizations and institutions. They should serve to alert authorities and the general public to antisemitic contents in the religious memories of Christianity and Islam.

- Christian and Muslim academics, teachers of religion, and clergy need to be educated about the antisemitic elements in their heritage. The institutes for antisemitism studies recommended in the present chapter on academic organizations and institutions could help with this educational effort.

- Christian and Muslim clergy and teachers of religion need to teach what they have learned about antisemitism in their parishes and school classes.

- Each religious group, organization, and institution should have a commission for relationship with the Jews that meets regularly with a comparable Jewish institution.

\subsection{Application of the Policies for Combating Antisemitism}

As detailed in the introduction to this catalogue, religious decision makers should combat antisemitism with both a short-term and long-term perspective. Policies that aim at restraining antisemitism in a religious, group, organization, or institution can be effective in a relatively short time span. Policies which aim at the eradication of antisemitism in the religious memories of a religious group, organization or institution will facilitate the eradication of antisemitism but can reach this (utopian) goal only in a time span of several generations of continual work. Policies that will help to achieve both goals will be listed below only once.

Policies that aim at the short term restraining of antisemitism in religious groups, organizations, or institutions include budgetary, disciplinary, organizational, and educational recommendations as well as those concerning interfaith understanding.

- Each Christian church and Muslim denomination should include a statement in their constitutions that antisemitism is incompatible with Christianity and Islam. 
- Positive examples of such statements include the fourth paragraph of the declaration Nostra Aetate of the Second Vatican Council.

- If such declarations do not exist already, church councils or councils of imams should be convened to create them.

- Each religious group, organization, or institution should endorse and apply the IHRA Working Definition of Antisemitism (see 565-6).

- As much as possible, Christians and Muslims should experience living Judaism and thus learn by way of experience to regard Jews as fellow human beings who are members of a different but equally valid and legitimate religious community.

- Theological studies of Christian and Muslim clergy and teachers should be complemented by mandatory classes in Jewish studies.

- Each religious group, organization or institution needs to spend at least percent of its budget to restrain and eradicate antisemitism among its members and in its religious traditions.

- Antisemitic organizations and institutions inside a Christian or Muslim denomination,

- such as the Polish Radio Maryja mentioned above, need to be dissolved.

- Clerics and employees of religious groups, organizations, and institutions identified as antisemites need to be defrocked, suspended from duty, and/ or excommunicated. This is especially true for teachers of religion, clerics, and professors.

- When antisemitic rumors arise, religious leaders must stand up immediately and denounce them.

- Depending on their size, each religious group, organization, or institution needs to have an envoy for combating antisemitism whose work should be supported by a Jewish-Christian or a Jewish-Muslim committee, respectively.

- A phone hotline and a Webpage should be created via which the office of the envoy for combating antisemitism that we recommend to authorities can be alerted to antisemitic agitation in sermons and other religious communications. Reports about such religious antisemitic agitation should always be investigated and, if necessary, public or religious authorities should act appropriately.

- No religious group, organization, or institution should participate in the BDS movement or in any other anti-Zionist activity that rejects the self-determination of the Jewish people. Legitimate criticism of Israel should, of course, not be affected by this recommendation.

- Religious groups, organizations, and institutions should condemn such antiZionist activities as antisemitism. 
Policies that aim at the long-term eradication of antisemitism focus on the religious memories of religious groups and organizations. Many of these recommendations are specific policies geared towards either Christianity, Islam or Judaism.

- The study of Hebrew Bible and Rabbinic literature should become mandatory in the

- religious education of Christian and Muslim clerics and teachers of religion.

- Christians and Muslims should acknowledge that the Hebrew Bible lies at the heart of their own religious traditions and should recognize the ongoing validity of the Jewish approach to Judaism's holy writ.

- Liturgical, educational, and doctrinal texts need to be assessed for antisemitic elements. Such antisemitic contents should be replaced by employing positive traditions about Jews and Judaism in Christianity and Islam.

- Liturgical, educational, and doctrinal texts need to be assessed for antisemitic elements including inappropriate language, such as using the word Pharisee as an insult in a Christian context.

- Instead of antisemitic canards, stereotypes and topics, liturgical, educational, and doctrinal texts should emphasize those episodes in the history of Christianity and Islam that include positive attitudes towards, and experiences with, Judaism.

Another important factor is that Christianity and Islam should acknowledge Judaism as a living religion whose heritage has grown and developed on its own since the parting of the ways of Judaism, Christianity, and Islam. The Judaism of today is not the Judaism of antiquity or the early Middle Ages. It is thus not enough to educate Christians and Muslims about how Christianity and Islam are rooted in Judaism. In order to eradicate Christian and Muslim Jew-hatred, Christians and Muslims also need to learn to accept living Judaism as a separate but equally valid sibling religion that advances its own way to salvation. The more Christians and Muslims encounter Jews, Jewish practices, and Jewish struggles and dilemmas, the more accepting and approving they will become of living Judaism. 
Especially important in this context are interfaith prayer events between Jews, Christians, and Muslims. Their shared emotional experiences are best suited to overcome religious hatred or immunize against it. A good practice example is the Kehilat Tzion congregation of Rabbi Tamar Elad-Appelbaum who regularly prays together with Christian and Muslim congregations in Jerusalem, thus creating mutual religious respect and acceptance among the Jewish, Christian, and Muslim members of these congregations. ${ }^{4}$ As far as their religious convictions allow for this, Jewish communities should participate in interfaith prayers.

Respect for other people's faiths, and learning from each other's wisdom and experiences is a preventative tool and remedy to prejudices, suspicions, and hostilities. Meetings, dialogues, and sharing knowledge can assist in healing tensions and installing trust. It is often the first stage on the road to mutual respect and peaceful coexistence. The best preventative measure to combat antisemitism is by acquainting people with the people they are prone to hate, and to do so in an agreeable, non-offensive manner. Ignorance and unfamiliarity are essential to the rise of prejudices and hatred.

- All Christians and Muslims, but especially those Christians and Muslims that are educators, clerics, or religious decision makers, should gather practical experiences with living Judaism by visiting synagogues, cooperating with Jews on joint projects, visiting Israel, and participating in associations for Jewish-Christian dialogue.

- Christian and Muslim religious education should include classes on Judaism taught by Jewish studies experts or especially trained experts on all levels of education. Curricula for these classes need to be developed.

- Christian and Muslim religious education should include classes on the history of Christian and Muslim antisemitism in all levels of Christian and Muslim education. Curricula for these classes need to be developed.

- Christian and Muslim schoolteachers and textbook authors as well as clerics should participate in workshops about the history, culture, and religion of Judaism taught by Jewish scholars and/or experts in Jewish studies. These workshops should be mandatory.

4 The Kehilat Zion congregation regularly organizes interfaith prayers, concerts and other religious events. Recently, Rabbi Tamar Elad-Appelbaum also started Israel's first interfaith charitable cooperative. Cf. B. Kissileff, "Re-dreaming Jerusalem: The Unorthodox Vision of Rabbi Tamar Elad-Appelbaum,” Voices of Conservative/Masorti Judaism, http://www.cjvoices.org/article/re-dreaming-jerusalem/. More information about Kehilat Zion, prayer times and interfaith events can be found on the official website of the congregation at https://studiodov.wixsite. com/kehilat-zion (accessed October 2, 2018). 
- Christian and Muslim schoolteachers and textbook authors as well as clerics should participate in workshops about the history of antisemitism. These workshops should be mandatory.

- Children's books, textbooks, study books, and popular books educating Christians and Muslims about Judaism and the history of antisemitism are needed.

- Christians and Muslims, as well as Christian and Muslim institutions, should participate in family and cultural exchange programs.

- Programs that allow young Christian and Muslim leaders as well as future Christian and Muslim decision makers to study in Israel at Israeli educational institutions should be supported and/or created.

- A scholarly seminar/seminar series should be created where Jewish, Christian, and Muslim scholars together wrestle with difficult texts, perhaps resulting in a university textbook that works with the text and presents different perspectives.

- Interfaith meetings, workshops and discussions are recommended as tools to develop mutual respect and understanding.

The irrational fervor of antisemitism demonstrates that antisemitism is more than anything else a belief system. Antisemitic thought is a system of religious symbols that developed in antiquity and continues to evolve today. Christianity, and later on Islam, dispersed the antisemitic system of religious symbols over the world. In modern times, antisemitism also began to occur connected to neither Christianity nor Islam, but maintaining its religious character. Therefore, Christianity and Islam have a particular responsibility to participate in the fight against antisemitism beyond the limits of their denominations. Experience demonstrates that antisemites are deaf to rational arguments against Jew-hatred. The religious character of antisemitism and its irrational fervor immunize those who hate Jews against rational education. Beyond the removal and/or neutralization of antisemitic stereotypes and canards in the Christian and Muslim religious memories, Christian and Muslim religious groups which are only sparsely affected by antisemitism, or free of it, should therefore fight against Christian and Muslim antisemitism, respectively.

Given their experience in missionizing, Christian churches, groups, organizations, and institutions have an important tool at their disposal to fight antisemitism on a religious level, disconnected from rational arguments. Those Christian churches, groups, organizations, and institutions who liberated themselves from the antisemitic heritage of Christianity, or are well on their way towards that goal, have a particular responsibility. They should use their experience to encourage antisemites to change their religious orientation from a religion of 
hate to a religion of love and mutual respect that includes the love of and respect for Judaism. They must guide the Christian antisemitic believer to the sources of Christian love and respect for the Jewish other.

Those Muslim groups and organizations that have only a low level of antisemitism or no antisemitism are as essential for successfully combating antisemitism. Like Christianity, Islam also understands itself as a religion of love, and in Muslim tradition this led to a positive attitude towards Judaism. Those Muslims belonging to more moderate and tolerant forms of Islam should draw on this idea to transform the attitude of their antisemitic brethren from Islamist hate to the mindset of Islam as a religion of love. A good practice example is the work of Imam Hassen Chalghoumi, the president of the Conférence des imams de France.

\section{Adjusting the Above Policy Recommendations to Judaism, Christianity and Islam}

\subsection{Christianity}

To combat antisemitism in Christianity successfully, it is important to understand that Christianity is very heterogeneous. It consists of 45,000 Christian denominations ${ }^{5}$ and a multitude of Christian groups, organizations and institutions each of which distinguishes itself from the other Christian denominations, groups, organizations and institutions. While most of the Christian churches are rather small, several belong to the largest religious groups worldwide and have tremendous influence. It always has to be kept in mind, that what applies to one Christian church might be radically different in many other Christian groups. The deliberations below strive to describe a paradigmatic process that needs to be adapted to each Christian denomination, church, group, organization, and institution.

In the beginning of Christianity, Christian identity was defined in contradistinction to Judaism. Christianity understood itself as the inheritor of God's promises of salvation to Judaism and thus the true Israel. Christians understood Judaism's rejection of the Messianic character of Jesus of Nazareth and the Christian idea of salvation through Jesus's sacrifice on the cross as a rejection of God's covenant with Israel that found its ultimate expression in the deicide libel, claiming

5 For number of Christian denominations in 2014, see http://www.gordonconwell.edu/re sources/documents/StatusOfGlobalMission.pdf 
that the Jews collectively had crucified Jesus. Judaism was construed as part of a demonic counterworld. Christian religious group identity was thus built not only in rejection of Judaism but by way of the demonization of the Jews. Various antisemitic stereotypes such as the blood libel grew out of Christian replacement ideology or supersessionism. Nevertheless, Christian replacement theology and became part of the religious memories of the various Christian denominations and churches and thrives even today.

Christianity claims that the salvation prophecies of the Old Testament regarding Jesus of Nazareth represent an important part of Christian replacement theology. For the eradication of antisemitism from Christian thought, it is important to recognize that the Hebrew Bible is not the Christian Old Testament but the Jewish Scriptures. In Christian thought salvation came to the world through Jesus of Nazareth. Yet it cannot negate, even by means of the New Testament, the promises of salvation to Israel made in the Jewish scriptures.

To fight Christian antisemitism successfully, an alternative approach to Christian identity building is needed that does not make Christian religious identity dependent on its contradistinction from Judaism. To build a Christian identity disconnected from antisemitic replacement theology is therefore a key factor for the eradication of antisemitism in the Christian religious memory. To achieve this goal, negative memory spaces about Judaism need to be removed from the Christian religious memory and replaced by positive ones. In other words, antisemitic stereotypes and patterns of thought need to be removed from the Christian religious memory, or, if this is not possible, neutralized. Those religious traditions that foster a positive appreciation of Judaism need to be strengthened. Persons and events in the history of Christianity that appreciate Judaism and/or fight antisemitism need to be highlighted in Christian religious memories. An example of such a person would be Sister Rose Thering. ${ }^{6}$ Counter-narratives, counter-myths, and counter-dogmata to antisemitic stereotypes need to be embedded into the religious memories of the Christian churches, groups, organizations, and

6 Sister Rose Thering (1920-2006) was a nun of the Dominican Order and Professor at Seton Hall University, New Jersey. Within her church, she actively battled antisemitism and her doctoral research contributed to the Vatican's declaration Nostra Aetate in 1965. She continued her interfaith work until high age and was the first woman ever to receive the Anti-Defamation League’s Cardinal Bea Interfaith Award in 2004. Cf. “About Sister Rose,” Seton Hall University, Sister Rose Thering Fund for Education in Jewish-Christian Studies, https://www.shu.edu/sister-rose/about-sister-rose.cfm (accessed October 2, 2018); R. D. McFadden, "Sister Rose Thering, Nun Dedicated to Bridging Gap With Judaism, Dies at 85,” The New York Times, May 8, 2006, https://www.nytimes.com/2006/05/08/nyregion/08thering.html?r=2\&scp=1\&sq=sister\%20rose\% 20thering\&st $=$ cse\&. 
institutions through education and a conscious effort to develop positive views on Judaism in Christian thought based on the Jewish origin of Christianity. This process involves not only changing official church documents and dogmatic decisions but more importantly changing the beliefs and belief-systems of the members of the various Christian churches. This goal can only be achieved in a long-term process in which doctrinal decisions of the churches can be communicated to the masses of Christian believers. A key factor in achieving these changes in the beliefs and convictions of Christian believers is religious education on all levels.

Religious topics that are already part of the Christian religious memory but assure a positive perception of Judaism should be highlighted and emphasized. These topics include the Jewish background and origin of Christianity: Jesus of Nazareth was a Jew. Although Paul distanced himself from Judaism, his roots are Jewish and his thought is thoroughly grounded in Judaism. As with the writings of Paul, the New Testament as a whole is indebted to Jewish thought. It is of key importance to emphasize on all levels of Christian thought how Christian theology is thoroughly grounded in its Jewish heritage. Tools to help achieve this goal could be study editions of the New Testament and other early Christian literature explaining this Jewish heritage inside Christianity by way of annotation. A good practice model is the Jewish Annotated New Testament. ${ }^{7}$ Christianity needs to acknowledge that it emerged from the matrix of Judaism.

In addition to the general policies outlined above for all religious groups, the following strategies to combat antisemitism are recommended to Christian religious decision makers and influencers.

- Literal (and historical-critical) instead of allegorical readings of the Jewish scriptures will help to emphasize their Jewishness and will help Christians to recognize the validity of Jewish interpretations of the Bible and hence the validity of Jewish claims to salvation. In this way, Christians will learn to understand the Jewish scriptures as the Hebrew Bible and not as the Old Testament. A literal historical-critical approach to the Bible has the potential to qualify Judaism to its Christian readers as an earlier and equally valid religion by anchoring a Jewish understanding of the Jewish scriptures in the Christian religious memory.

- A proper understanding of the Jewish scriptures and their reception in the New Testament has the potential to help Christians understand that the Jews are equally God's chosen people. Christians need to recognize God's

7 A. J. Levine and M. Z. Brettler, eds., The Jewish annotated New Testament: New Revised Standard Version Bible Translation (Oxford: Oxford University Press, 2011). 
promises of salvation to Israel were, even according to their own tradition, never withdrawn from the Jewish people but are still valid as already attested in Jesus' preaching.

- Much of New Testament thought is grounded in the religious thought of ancient Judaism expressed in non-biblical texts. The promotion of the study of non-biblical ancient Jewish literature could thus educate Christians as to how much their religious understanding and their hopes for salvation grew out of Judaism, i.e., to understand that Christianity did not replace Judaism but was delivered to the world by it.

- Texts like Nostra Aetate need to be highlighted as parts of the Christian cultural memory that express respect and appreciation of Judaism.

- Christian personalities who engaged in a positive relationship with Jews and Judaism need to be highlighted in Christian religious memories, if possible they should even be beatified or sainted. An example for such outstanding personalities is Sister Rose Thering.

- Future explicit and official ecclesiastical statements need to take into account the historical relationships of Judaism and Christianity and to reject Christian supersessionism and any antisemitic stereotypes in the Christian religious memories.

- It is of key importance that any new liturgical and/or doctrinal documents are communicated to the membership of Christian churches. While some Churches have formulated important doctrinal documents rejecting antisemitism and have even begun to reformulate their liturgical texts, budgetary concerns and restrains keep them from communicating these measures to their members.

\subsection{Islam}

Although less diverse than Christianity, Islam is not a monolithic religion either but has several denominations, to which should be added various Islamic movements. Islam has changed over the long time of its existence. In addition to such historical developments, significant regional differences exist. So, for example, separate approaches are necessary for the fight against antisemitism by Muslims in the Western world, on the one hand, and by Arab and Muslim states, on the other hand. Much of the general policies recommended to religious decision makers in part 3.1 of this catalogue will necessarily apply more to Muslim communities in the Western world than to Arab and Muslim states. However, the changes in Islamic discourses on antisemitism and Holocaust denial and the 
changing strategic circumstances in the Middle East could point to an openness to our suggestions beyond the Muslim diaspora in the Western world.

Some general remarks are possible nevertheless: The Quran itself is not free of antisemitism, and early and medieval Islam are also no strangers to Jew-hatred. Examples include the 1033 Fez massacre and 1066 pogrom of Granada. For example, despite their second class status in Islamic societies, many Sephardic Jews fled in 1492 from the Spanish Inquisition to the Ottoman Empire. Although antisemitism existed in early and medieval Islam, substantial elements of contemporary Islamic antisemitism agree neither with Islam's foundational period nor with the Muslim Holy Scriptures. Many aspects of modern Islamic antisemitism were imported from Christianity and the Western world. The impact of Christian antisemitism on the Muslim world began in the $19^{\text {th }}$ century and accelerated during and after the Nazi period. While it is a common feature of contemporary Muslim antisemitic agitation to accuse Jews of drinking blood, the earliest occasion of a blood libel in the Muslim world is the so-called Damascus Affair of 1840 in which French-Christian diplomats introduced this slander to Islam.

Common antisemitic notions, features and symbols are thus often alien to Islamic culture and heritage, and they are nothing more than the importation of concepts that were invented and prevailed in the medieval and modern Christian world. Muslims are generally skeptical about the religious validity of Christian thought but hold Quran, Hadith and Sira supreme. To show that much of the ideology of current Muslim antisemitism goes back to Christian antisemitic thought might therefore help to overcome Muslim Jew-hatred.

Muslim thinkers often describe the essence of Islam as rooted in love, and Islam would share this opinion with other religions. Shams al-Din Muhammad who is known by his pen name "Hafiz" is an example:

Drunk or sober, we're all seekers of the beloved:

Mosque or Synagogue-everywhere is the house of love. ${ }^{8}$

Imam Chalghoumi often emphasized during our conference that Jew-hatred is irreconcilable with Islam as a religion of love. To those Muslim decision makers and influencers who do not share in antisemitic prejudices, we therefore recommend the following policies.

- Emphasize positive depictions of Jews and Judaism in Quran, Hadith, and Sira against antisemitic agitation.

8 Ḥāfiz, The Poems of Hafez, transl. R. Ordoubadian (Bethesda: Ibex Publishers, 2006), 98. 
- When Quran, Hadith, or Sira polemize against Jews or Judaism, cross-references to those parts of these scriptures should be added that describe Jews positively to counterbalance the antisemitism in Muslim scriptures.

- Emphasize those parts of Quran, Hadith, and Sira which advocate a peaceful coexistence of Muslims, Jews, and Christians such as the Constitution of Medina (622 C.E.).

- Highlight the positive and tolerant verses in the Quran toward the Jews beside the negative ones. Religious scriptures cannot be changed, but their interpretation is crucial and can be adapted to goals of coexistence.

- To translations and editions of the Quran, Hadith and Sira, notes should be added to the effect that the some of the seemingly antisemitic passages are ambiguous, and their meaning is greatly dependent on their interpretation.

- Emphasize that the purported breach of the Constitution of Medina concerned-if at all-some Jewish tribes of the Arab diaspora but not all of Judaism.

- Emphasize that Jew-hatred violates the basic principles of Islam and disagrees with much of the Islam's religious memory.

Along with the above recommendations concerning the depiction of Jews and Judaism in the religious memory of Islam, much can be done to further a peaceful co-existence between Muslim and Jewish communities both the Western and Muslim worlds. To facilitate that goal, we recommend Muslim religious decision makers and influencers begin:

- To educate Muslims about the history of Muslim antisemitism calling attention to the elements of Christian and Western orgin.

- To educate the broader Muslim public accurately about the history of Jews in the Muslim world as well as about the history of Jewish-Muslim relations.

- To educate Muslims about the commonalities of Islam and Judaism.

- To accurately inform a broader Muslim public about the history of the State of Israel.

- To accurately inform a broader Muslim public about the life of Israel's Muslim citizens:

- Israeli Muslims enjoy more civil rights, a better education, and a better standard of life than Muslims do in almost all other parts of the Arab world.

- $\quad$ To provide an accurate depiction of the Jew's Dhimmi status in Islam as a disadvantaged minority.

- To form an alliance that brings together those Muslims, ex-Muslims and nonMuslims who want to fight Islamic antisemitism and Islamism. 
Many antisemitic ideas are employed today to advance an anti-Zionist agenda against the State of Israel by Muslim individuals and states. This anti-Zionist agitation goes beyond the legitimate criticism exercised against any state. This catalogue is not the place to address the problems of the Israeli-Palestinian conflict. From a perspective of Islam, it should be emphasized by Muslim religious decision makers that the Qur'an grants the land of Israel to the Jews. References used by Muslim supporters of Israel are Suras 5:21; 17:104 and 26:59 in this context. Good practice examples are Sheikh Prof. Abdul Hadi Palazzi, Director of the Cultural Institute of the Italian Islamic Community ${ }^{9}$ and the Jordanian Quranic scholar Sheikh Ahmad al-Adwan. ${ }^{10}$

\section{Recommendations for Arab and Muslim states}

Many of the policy recommendations on how to fight the antisemitism of and in Arab and Muslim states concern political decision makers and not religious ones. We therefore direct the reader also to the chapter addressed to political decision makers (see below, 529-61).

- Encourage education on the history of Jewish communities in Arab and Muslim lands and past Muslim-Jewish relations with both their negative and positive aspects.

- Encourage interfaith dialogue as well as Jewish-Arab-Muslim meetings for the discussion of issues of mutual interest, such as the meeting of Iraqi poets and writers with former Iraqi Jews in October 2017 in Berlin. The attendees discussed the Jewish cultural contribution in Iraq and the reasons for the demise of the community.

\section{Recommendations for Muslims in the Western World}

Many of the recommendations below concern are not limited only to Muslim religious decision makers and influencers in the Muslim world. We list them here,

9 Cf. S. Behrisch, “The Zionist Imam,” The Jerusalem Post, July 19, 2010, https://www.jpost.com/ Christian-In-Israel/Blogs/The-Zionist-Imam; M. Radler, “A Different Kind of Muslim,” The Jerusalem Post, April 18, 2004, http://www.jewishtruths.com/files/NewsMaker.pdf.

10 Cf. A. Yashar, “'Allah Gave Israel to The Jews, There’s No Palestine'," Arutz Sheva, June 2, 2014, http://www.israelnationalnews.com/News/News.aspx/177182; J. Levitt, “Jordan’s 'Zionist Sheikh' Cites Quranic Sources for Islam-Jewish Relations,” The Algemeiner, March 7, 2014, https://www.algemeiner.com/2014/03/07/jordans-zionist-sheikh-cites-quranic-sources-for-islamjewish-relations/. 
nevertheless, as they can and should be applied both inside and outside of Muslim communities in the Western world as well. Furthermore, much of Muslim antisemitism and especially Muslim anti-Zionism, is inspired by propaganda and agitation from Muslim states such as Hamas-run Gaza, Iran, and Turkey. The fight against Islamic antisemitism in the Muslim communities of the Western world will hence remain ineffective as long as Jew-hatred incessantly manipulates Muslims in Europe via social networks or state media in Turkish, Arabic or Farsi languages. Only governments can stop this flow of hate messages. We direct the attention of the reader also towards our recommendations to political decision makers (see below, 529-61).

- Cooperate closely in the fight against antisemitism with local public authorities.

- Enhance interfaith dialogue.

- Encourage Muslim-Jewish cooperation in fighting against issues of mutual concern, such as challenges to religious rights including bans of kosher or halal slaughter and circumcision.

- Identify and legally fight Muslim organizations that engage in incitement and antisemitic activities.

\subsection{Judaism}

As with Christianity and Islam, Judaism is not monolithic but a diverse religion. When we speak here of Judaism in general, we do so because we hope that our recommendations will be considered by religious leaders of all groups of Judaism. This chapter is addressed in particular to religious decision makers, and we restrict the policy recommendations below, therefore, to the contributions religious Jewish communities could make in the fight against antisemitism, being well aware that there are Jews whom they do not represent.

Since Jews were and are for the most part victims of antisemitism, the elimination of antisemitism can only happen as a result of a major change in the attitudes of others. However, the extensive efforts of the Jewish community in combating antisemitism have accomplished much, and we expect that they can continue to contribute greatly. It goes without saying that these activities should continue and be expanded. Nevertheless, the responsibility for the elimination of this evil lies outside the Jewish community.

Jewish tradition thinks highly of interfaith encounters. An example for this appreciation are two passages from the Torah and the Talmud. They rule that Jews should accept others without prejudice or bias. 


\begin{abstract}
You shall not hate your kinsfolk in your heart. Reprove your kinsman, but incur no guilt because of him. You shall not take vengeance or bear a grudge against your countrymen. Love your fellow as yourself: I am the Lord (Lev 19:17-18).

We support the poor of the non-Jew with the poor of Israel and visit the sick of the non-Jew along with the sick of Israel and bury the dead of the non-Jew along with the dead of Israel, for the sake of peace (b. Git. 61a)

In a city where there are both Jews and Gentiles, the collectors of alms collect from both Jews and Gentiles; they feed the poor of both, visit the sick of both; bury both and restore the lost goods of both, for the sake of peace (y. Demai 4:6).
\end{abstract}

Though this chapter deals with religious leaders, we cannot ignore the fact that other parts of the Jewish people contribute to the commandment to accept the other, each in his/her way. Secular Jews, whether in Israel or abroad, and Jewish groups of a universalist worldview are all capable of opening up to work with non-Jewish groups and individuals, in a variety of ways to counter antisemitism.

This Jewish openness to non-Jews allows for interfaith encounters that have a key role the fight against antisemitism. They are important on various levels. We therefore recommend the following policies to Jewish religious decision makers and communities.

- Continue to expand ongoing relations of Jewish religious decision makers and influencers with the leadership of Christian and moderate Muslim groups to help to facilitate doctrinal changes away from Christian or Muslim antisemitism. A well-known example is the role the American Jewish Committee played in the writing of Nostra Aetate.

- Jewish communities and religious decision makers should support and enlarge existing exchange programs and cooperative initiatives and create new ones whenever appropriate.

- Jewish religious decision makers and/or organizations should participate in the development of curricula and textbooks to educate Christians and Muslims about Judaism.

- Jewish religious decision makers should participate in interfaith dialogue with Christian and Muslim theologians to educate them about Jewish thought and religion.

- Jewish religious decision makers should extend every effort to educate nonJews about Judaism. Good practice examples include the new Muslim Jewish Interfaith Coalition (https://www.themjic.org) and the Jewish Christian Muslim Association of Australia (http://jcma.org.au). Similarly, the European Jewish Congress, organizes an annual seminar in cooperation with the Holy See's Commission for Religious Relations with the Jews, bringing together young European community and interfaith activists. 
- All Jewish denominations should participate in outreach programs that will provide Muslim and Christian religious decision makers with first hand positive experiences about Judaism. Jewish communities should invite Christian and Muslim decision makers and influencers, as well as Christian and Muslim school classes, to the synagogue or to celebrate together Jewish holidays like Shabbat, Hanukah, or Purim. The participation in synagogue services, Jewish celebrations of holidays, or bar mitzvot and bat mitzvot would allow non-Jews to see Judaism and Jews in a more human and friendly manner.

- To immunize against antisemitism and to change antisemitic minds one at a time, emotional experiences are a necessary key because they are best suited to create positive emotional experiences with the Jewish religion among non-Jews. We therefore recommend that as far as their religious convictions allow for it, Jewish communities should participate in interfaith prayers. The good practice example of the work of Tamar Elad-Appelbaum was already mentioned above.

- Combat xenophobic attitudes of Jews and Israelis toward Arabs and Muslims. Israel can serve as a positive model for inter-confessional relations.

\section{To Summarize}

Both Christianity and Islam contributed much to transmission of antisemitism over millennia. Antisemitic thought is deeply engraved into the religious memories of both Christianity and Islam. The fight against antisemitism is therefore a special responsibility of both religions. It is therefore of key importance to remove antisemitic stereotypes and canards from the religious memory of a religious group or institution. Instead, the positive memories about Judaism in a religious memory should be emphasized and new positive contents about Judaism should be added to religious memories. The authorization of antisemitic role models such as saints or highly respected authorities that provide guidance to the members of a religious group or institutions should be removed. Antisemitic clergy and antisemitic teachers of religion should be dismissed. All Christians and Muslims, but especially those Christians and Muslims that are educators, clerics, or religious decision makers should garner practical experiences with living Judaism by visiting synagogues, cooperating with Jews on joint projects, visiting Israel, and participating in associations for Jewish-Christian dialogue. Interfaith events between Jews, Christian and Muslims are particularly important to overcome the Jew-hatred of Christian and Muslim antisemitism. 